\title{
The Effect of Participative Leadership of Principal of Private School on Work Motivation of Teacher and their Performance in Tangerang City
}

\author{
Suparno, Vina Iasha, Apri Wahyudi, Phong Thanh Nguyen
}

\begin{abstract}
This study aimed to determine the effect of participative leadership of principal factors and work motivation of teacher on teacher performance in private schools in Tangerang City. This study is a a quantitative approach targeting on private school teachers. The instrument used was a questionnaire. The validity of the instrument is in the form of logical validity and empirical validity using Pearson Product Moment. Reliability test used the Cronbach Alpha formula. The data analysis technique used was simple regression and multiple regression. This study obtained information that the contribution of participative leadership of principal to teacher performance was $53.1 \%$. The contribution of work motivation of teacher to teacher performance was $54.2 \%$. While simultaneously, the contribution of the participative leadership of principal and teacher work motivation together on teacher performance amounted to $64.3 \%$, while the rest were influenced by other factors.
\end{abstract}

Keywords: participative leadership, work motivtaion, teachers' performance.

\section{INTRODUCTION}

The principal plays a central role as the driving force for school progress. In addition, the Principal's job is to plan, organize, develop staff, mobilize school staff, coordinate, and control various resources to achieve school goals effectively and efficiently. The principal is also tasked with preparing the budget plan and making periodic reports on the activities that have been carried out. Therefore, the Principal must understand these functions well, be visionary and have a persuasive style so that they have a great opportunity to improve the competencies of the teachers and their schools (Baharun, 2017).

Leadership is a process that contains elements of influence, the existence of cooperation and leads to a thing and common goals in the dynamics of organizational life. The success of an organization in achieving its intended goals, will very much depend on the role of its leader. Likewise, with leadership in schools, the pattern of behavior

Revised Manuscript Received on July 22, 2019

* Correspondence Author

Suparno , Faculty of Teacher Training \& Education, Sultan Ageng Tirtayasa University. E-mail: suparno101 @untirta.ac.id

Vina Iasha, Primary Education, Jakarta State Uiversity.

E-mail: vina.iasha@gmail.com

Apri Wahyudi*, Madrasah Ibtidaiyah Teacher Training, Sekolah Tinggi Ilmu Tarbiyah. E-mail: apriwahyudi@ stitpringsewu.ac.id

Phong Thanh Nguyen* Department of Project Management, Ho Chi Minh City Open University, Vietnam. E-mail: phong.nt@ou.edu.vn or leadership style applied by the principal will be very influential in determining the direction and education policy that is built. The principal must be able to mobilize and empower all the potential that exists in the school, related to carrying out various programs, processes, evaluations, curriculum development, learning in schools, extracurricular activities, processing of teaching staff, facilities and infrastructure, services to students and parents, relations to the community even to the school climate that is conducive, safe, comfortable, an orderly learning process, so that school and educational goals can be achieved.

The applied leadership will influence the behavior of subordinates and the creation of a working climate, whether it leads to positive or vice versa. The attitude of the principal who lacks authority, is not assertive, and behaves indifferently towards subordinates will create an atmosphere of educational climate and an uncomfortable learning process. While the attitude of a principal who is authoritative, decisive, fair and attentive to subordinates or teachers and students, will create a harmonious and comfortable educational atmosphere in learning and even the creation of an educational achievement. Therefore, an organization's leadership needs to develop traits and build a motivational climate that results in a high level of productivity, so that teachers can teach well.

Visionary views and leadership style on the management of institutions or organizations determine the effectiveness of leadership, because a leader who has the right leadership style will be able to realize the goals he wants to achieve. The ability of a leader to direct and move the people who are led depends on the leadership style of the leader. There are several leadership styles that can be applied by leaders that reflect the behavior of leaders, especially in education. One of the leadership styles is participative leadership.

Participative leadership consists of inviting followers to share in the decision making. A participative leader consults with followers, obtains their ideas and opinions, and integrates their suggestions into the decisions about how the group or organization will proceed (Northouse, 2017, p. 118). Participative leadership can be interpreted as inviting subordinates to be involved in decision making. Participative leaders consult with subordinates, get their ideas and opinions, and integrate suggestions into decisions about how the group or organization will move forward. 
(Yukl, 2015, p. 99) said that participative leadership is the manager's effort to encourage and facilitate the participation of others in important decision making. Participative leadership involves the use of various kinds of decision procedures that give others a certain influence on the leader's decision. Other terms commonly used to refer to aspects of participative leadership include consultation, joint decision making, power sharing, decentralization, empowerment, and democratic management.

Wirawan (2014, p. 382) argued that participative leadership is a style that is in the middle where the amount of power and freedom to use the power between leaders and followers is equal. The leader and the followers must actively participate in planning, carrying out and evaluating the results. Dimyati (2014, p. 39) stated that participative leadership is a way of leading that allows subordinates to participate in the decision-making process if the process affects the group, or the group (subordinates) can play a role in decision making.

As for Susanto (2016, p. 9) stated that participative leadership is performing persuasive leadership, creating harmonious cooperation, fostering loyalty and participation of subordinates. Leaders motivate subordinates to belong to the organization. In this sense, the leader will be encouraged to always nurture subordinates to accept greater responsibility. Basri (2014, p. 125) stated that participative leadership is a way of leading that allows subordinates to participate in the decision-making process. In this definition, if the process influences the group or the group in question can play a role in decision making, the leader will not only provide opportunities for those who take the initiative but also helps to complete the tasks. In other words, this type of leadership involves the participation of subordinates in carrying out their duties and obligations as a leader.

From various definitions, participative leadership is leadership that emphasizes group work up to the bottom level, in the process of decision making and determining targets, leaders always involve subordinates with two-way communication patterns so as to give freedom to subordinates to convey all ideas or problems related to implementation meaningful work shows openness and high trust in subordinates.

The results of research by Mbeu and Anwar (2011) and Werang (2014) provided clues that the principal leadership model must have high achievement motivation, one of which is entrepreneurial leadership. As for school students, achievement motivation is an important factor for learning success (Joseph, 2010; Fatchurrochman, 2011). In addition, the principal achievement motivation was useful in influencing work motivation on teacher performance at school by $87.00 \%$ (Manik \& Bustomi, 2011).

The results of research conducted by Adi (2013) proved that the school's organizational culture, principal leadership, and principal's work motivation directly influence the principal's organizational commitment and to the principal's performance. These findings indicate that if each of these variables is in a conducive, effective, and high condition, it will be able to influence the increase in the commitment of the principal organization and in turn will have implications for improving the performance of the principal. Through the high-performance of principal, it is expected to be able to encourage improvement in the quality of education in schools.

Some literature states that participative leadership is leadership that can create fundamental changes and is based on cultural values to create innovation and creativity of followers in order to achieve a predetermined vision. A participative leader has a clear vision, has a holistic picture of how the organization will be in the future when all goals or objectives have been achieved (Somech, 2005; Bush, 2007).

One of the organizational resources that has an important role in achieving organizational goals is human resources. Therefore, the quality of teaching staff (teachers) and education staff (principals, supervisors, laboratory assistants, librarians, administrative staff, instructors) must be improved. The teacher is an element of resources that determines the success of education in schools because the teacher is a human element that is very close to the relationship with students in the daily education efforts at school. The person who is responsible for implementing the learning process in class is the teacher. Improving the quality of teachers needs to be performed continuously so that good performance of teacher can be maintained. The quality of education is determined by the good performance of teachers who certainly can not be separated from elements of overall school management.

Teacher performance in schools has an important role in achieving school goals. Teacher performance is stated as good and satisfying if the objectives achieved are in accordance with established standards. Teacher performance is influenced by several factors, namely: (1) mental attitude (work motivation, work discipline, work ethics); (2) education; (3) skills; (4) leadership management; (5) level of income; (6) salary and health; (7) social security; (8) work climate; (9) infrastructure; (10) technology; (11) opportunities for achievement, as revealed by Sedarmayanti in Supardi (2013 : 19)

This teacher performance problem is the main problem based on interviews, most likely due to other problems related to principal leadership and problems related to teacher work motivation. Problems related to principal leadership, namely: (1) principals rarely give rewards to teachers who do their assignments well; (2) the principal does not ask for advice and opinions of teachers and staff if there are problems; (3) the principal does not give enough time to consult; (4) lack of equal opportunities for teachers and staff for self-development; (5) lack of enthusiasm and work motivation for teachers; (6) lack of information relating to the implementation of the teacher's tasks.

Some issues related to teacher work motivation include: (1) There are still teachers who are less enthusiastic in teaching; (2) Most teachers appear to be more diligent in working when the principal is in school; (3) lack of motivation to provide more services to students outside of teaching hours; (4) lack of personal effort to enrich knowledge especially for the subjects being taught, only relying on what is provided by the school.

In addition to the above problems, problems related to inadequate school
infrastructure, problems
regarding interactions with 
the community around the school, less intense communication with parents and lack of interaction and communication with the education office.

The success of teachers in carrying out their duties and obligations as educators in schools is largely determined by the enthusiasm of work or work motivation they have. Motivation is a very important variable in the efforts and needs of self-actualization to improve performance and assist leaders in achieving organizational goals.

Internal motivation is an impulse that arises from a person's conscience without being influenced by external factors. For example: a sense of responsibility, developing expertise, doing interesting work, autonomy or freedom of action and an opportunity to progress. Therefore, this is the main basis for growing motivation to succeed, develop, and be able to meet material and spiritual needs. External motivation arises due to stimulation from outside of a person's conscience. For example, salary/wages, working environment conditions, honorarium, benefits, promotions and incentives.

Based on the initial observations and interviews conducted on students and teachers in January 2017 in Korwil 1 Tangerang Private High School, the author saw a problem with teacher performance, a phenomenon that occurs showed that the performance of existing human resources was still not as expected, where the performance of teachers was not optimal in carrying out their main tasks. This can be seen with the following problems. (1) Around 20\% of teachers were still late coming to school; (2) around $15 \%$ of teachers did not come to work; (3) entering class late or leaving class early; (4) making learning devices that were not timely; (5) learning devices were not used optimally; (6) the teacher only gave assignments in class during teaching hours; (7) the teacher performed teaching in a less creative way which relied on the lecture method.

Schools with participative leadership supported by teachers who have high work motivation will produce performance output that is as expected. The success of the school is supported by synergistic cooperation between the principal, the teacher, the education staff, the participation of parents, the government and stakeholders who care about education. Teachers as implementers in learning should have good performance through high commitment and motivation towards their tasks and work.

With the description above, the authors were interested and intend to conduct research on "Relationship Between

Participative Leadership of Principal and Work Motivation with Teacher Performance in Korwil I Tangerang Private High School".

\section{METHOD}

This study used a quantitative approach. Data was collected at Korwil I Private High School, Tangerang City, Banten Province. The subjects of the study were teachers at the Korwil I Tangerang Private High School (SMA) which were held from July 2017 to January 2018.

This study was designed to obtain information about the relationship between different variables in a population consisting of three variables, namely two independent variables and one dependent variable.
The independent variables are participative leadership of principal (X1) and work motivation (X2). The dependent variable is teacher performance $(\mathrm{Y})$. This study presented the relationship between participative leadership in principal (X1) and work motivation (X2) with teacher performance (Y).

The population in this study were the teachers of Korwil I Tangerang Private High School in the Academic Year 2017/2018 as many as 121 people. The details of number of teachers is as in Table 1 below.

Table 1. Number of Teachers at Korwil I Tangerang Private High School

\begin{tabular}{|c|c|c|}
\hline No. & Name & $\begin{array}{c}\text { Number of } \\
\text { Teachers }\end{array}$ \\
\hline 1. & SMA Pribadi & 19 \\
\hline 2. & SMA Nusa Putra & 27 \\
\hline 3. & SMA Al-Wasatiya & 15 \\
\hline 4. & $\begin{array}{ll}\text { SMA } & \text { Perguruan } \\
\text { Buddhi } & \end{array}$ & 21 \\
\hline 5. & SMA Al-Husna & 17 \\
\hline \multirow[t]{2}{*}{6.} & SMA Nusantara I & 22 \\
\hline & Total & 121 \\
\hline
\end{tabular}

Because the population is relatively large, sampling is needed to save costs, time and energy. Looking at the characteristics of the average homogeneous population, it can be seen from the average level of education that is undergraduate of education and serves as a High School teacher. With that basis, the sampling technique with a simple random sampling method was used.

The sampling technique was performed by drawing. All the teacher's names were written on a small piece of paper and then rolled up and put in a stirred jar, then the draw was performed by taking one by one as many as the specified number of samples. The name of the teacher as drawing results was determined as a sample.

According to Sugiyono (2014, p. 128-129), the research sample was calculated using the Isaac and Michael formula as follows:

$$
S=\frac{\lambda^{2} N P Q}{d^{2}(N-1)+\lambda^{2} P Q}
$$

Description:

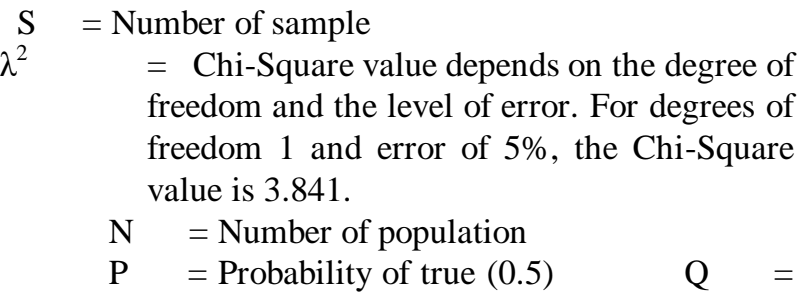
Probability of false $(0.5) \quad \mathrm{d} \quad=$ The difference between the expected sample and existed sample with $d$ of 0.05 . 
With a population of 121 people, the calculation was obtained that the total sample of 93 people. The sample used can be seen in the following Table 2 .

Table 2. Number of Samples in Every School

\begin{tabular}{|l|l|c|}
\hline No. & Name & $\begin{array}{l}\text { Number of } \\
\text { Samples }\end{array}$ \\
\hline 1. & SMA Pribadi & 15 \\
\hline 2. & SMA Nusa Putra & 21 \\
\hline 3. & SMA Al-Wasatiya & 11 \\
\hline 4. & $\begin{array}{l}\text { SMA Perguruan } \\
\text { Buddhi }\end{array}$ & 16 \\
\hline 5. & SMA Al-Husna & 13 \\
\hline 6. & SMA Nusantara I & 17 \\
\hline & Total & 93 \\
\hline
\end{tabular}

Data collection technique used questionnaires. In this study, the questionnaire was used to collect the required data regarding the perception of participative leadership of principal, work motivation, and teacher performance. The preparation of the questionnaire was carried out using a modified rating scale measurement. Respondents were given alternative answers, namely by choosing answers from intervals from 1 to 5 or from never to always. The scoring was performed by looking at the nature of the item.

This study collected three data, namely participative leadership of principal data based on teacher perceptions, work motivation and teacher performance. Data collection techniques began with defining conceptual definitions, operational definitions, instrument lines, testing instrument validity, and calculating reliability.

The instrument used to determine participative leadership of principal based on teacher perceptions and work motivation with teacher performance was an instrument in the form of questions with answers. The answer was in Likert scale interval data. According to Sugiyono (2014, p. 136), Likert scale was used to measure the attitudes, opinions, and perceptions of a person or group of people about social phenomena.

The questionnaire was arranged with items that were given the highest score to the lowest with five alternative answers, namely: The Always (SL) was given a score of 5, the Often (SR) was given a score of 4 , Sometimes $(\mathrm{KK})$ was given a score of 3, Very rarely (JS) was given a score of 2, and Never (TP) was given a score of 1 .

For Teacher Performance (Y) variable which is interpreted as a condition that shows the results and actions and effective teacher communication produces productivity and success in achieving school goals that are increasing student achievement. Thus the teacher's performance is a score obtained from the results of the distribution of closed questionnaires with dimensions: (1) Ability to draw up a learning plan, (2) Ability to carry out learning, (3) Ability to carry out interpersonal relationships, (4) Ability to carry out assessment of learning outcomes , (5) Ability to carry out enrichment programs, (6) Ability to carry out remedial programs.

Participative leadership of principal variable (X1) is leadership that emphasizes group work up to the bottom level, in the process of decision-making and determining the target, leaders always involve subordinates with two-way communication patterns so as to give freedom to subordinates to convey all ideas or related problems with the implementation of work which means showing openness and high trust in subordinates. Operational Definition of Participative leadership of principal in this study was obtained from the results of the distribution of closed questionnaires with dimensions: (1) Consultation, (2) Joint decision making (3) Power distribution, (4) Decentralization, (5) Empowerment, (6) Democratic management.

The work motivation of the teacher variable (X2) is a process of potential strength that exists inside or outside a person that explains the direction, intensity and perseverance carried out to achieve certain goals or needs. Operational Definition of Work Motivation is a score obtained from the results of the distribution of closed questionnaires with dimensions: (1) Intrinsic motivation which is a factor that comes from oneself that influences someone to take certain actions. With indicators namely responsibility, autonomy (freedom of action), opportunities to advance, develop skills, do interesting and challenging work, (2) Extrinsic Motivation which is a factor that comes from outside of a person or performed by others to motivate a person.

Validity testing in this study was conducted in two ways, namely by expert judgment and with content validity. Before the items of the instrument were used, they were first consulted to an expert and then conducted a trial to 30 respondents.

The following are the results of the instrument validity test, namely: (1) Based on the indicators of the participative leadership of principal variable (X1) which was developed into 30 statements, it turns out there were 27 valid statement items that would be used as research instruments and only 3 invalid statement items or fall, namely statement number 2,8 and 30; (2) Based on the indicators of the work motivation of teacher variable (X2) which was developed into 30 statements, it turns out there were 25 valid statement items that would be used as research instruments and 5 invalid statements, namely statement number 2, 8, 14, 16 and 18; and (3) Based on indicators of teacher performance variables (Y) which was developed into 40 statements, it turns out there were 33 valid statement items that would be used as research instruments and 7 invalid statements, namely statement number 3, 6, 11, 12, 15, 22 and 28 .

Invalid items were not included in research data collection. Valid statement items were used to reveal the relationship between participative leadership of principal and work motivation with teacher performance. So the number of items used in this study were 27 statement items for the participative leadership of principal variable, 25 statement items for work motivation of teacher and 33 statement items for teacher performance.

After testing the validity, then the instrument performed reliability test. Reliability shows the extent to which an instrument can be trusted to be 
used as a data collection tool. To find out whether the instrument was reliable or not, the next step was to consult with the value of criticism or reliability standards. The price of criticism for the instrument reliability index was 0.7 . This means that an instrument was declared reliable if it has an Alpha coefficient of at least 0.7 (Siregar, 2015, p. 90).

Furthermore, the reliability test results of the research items were compared with the value of the product-moment at a significant level of $5 \%$. If $r$ calculation $>r$ table, the instrument is reliable, and vice versa if the value of $r$ calculation $<\mathrm{r}$ table then the instrument was not reliable. Cronbach Alpa value for Participative leadership of principal (X1) variable was 0.892 , for Work Motivation of Teacher (X2) was 0.924, and for Teacher Performance variable (Y) was 0.970 .

\section{RESULTS AND DISCUSSION}

Data descriptions were obtained from distributing questionnaires using instruments developed and validated. Research data on the participative leadership of principal (X1), work motivation (X2) and teacher performance (Y) are presented as follows.

Participative leadership of principal questionnaire data based on teacher perceptions that contained 27 closed statement items was obtained from a questionnaire that had been distributed to 93 respondents.

Table 3. Description of Participative Leadership of Principal

\begin{tabular}{|l|l|l|}
\hline No & Statistic & Value \\
\hline 1. & Average & 109.09 \\
\hline 2. & Standard Deviation & 9.059 \\
\hline 3. & Median & 109 \\
\hline 4. & Mode & 106 \\
\hline 5. & Minimum & 89 \\
\hline 6. & Maximum & 129 \\
\hline
\end{tabular}

The data distribution of the participative leadership of principal variable $(\mathrm{X} 1)$ can be grouped in the frequency distribution per class as seen on the table below:

Table 4. Frequency distribution of the participative leadership of principal variable (X1)

\begin{tabular}{|l|l|l|l|l|}
\hline No & Range & Median & Frequency & $\begin{array}{l}\text { Relative } \\
\text { Frequency }\end{array}$ \\
\hline 1. & $81-90$ & 85.5 & 1 & 1 \\
\hline 2. & $91-100$ & 95.5 & 14 & 15.1 \\
\hline 3. & $101-110$ & 105.5 & 42 & 45.2 \\
\hline 4. & $111-120$ & 115.5 & 26 & 27.9 \\
\hline 5. & $121-130$ & 125.5 & 10 & 10.7 \\
\hline
\end{tabular}

Work motivation questionnaire data containing 25 closed statement items were obtained from questionnaires that had been distributed to 93 respondents.
Table 5. Description of Work Motivation (X2)

\begin{tabular}{|l|l|l|}
\hline No & Statistic & Value \\
\hline 1. & Average & 105.86 \\
\hline 2. & Standard Deviation & 10.242 \\
\hline 3. & Median & 107.00 \\
\hline 4. & Mode & 97 \\
\hline 5. & Minimum & 86 \\
\hline 6. & Maximum & 125 \\
\hline
\end{tabular}

Table 6. Frequency distribution of the work motivation (X2)

\begin{tabular}{|l|l|l|l|l|}
\hline No & Range & Median & Frequency & $\begin{array}{l}\text { Relative } \\
\text { Frequenc } \\
y\end{array}$ \\
\hline 1. & $81-90$ & 85.5 & 10 & 10.8 \\
\hline 2. & $91-100$ & 95.5 & 15 & 16.1 \\
\hline 3. & $101-110$ & 105.5 & 38 & 40.9 \\
\hline 4. & $111-120$ & 115.5 & 23 & 24.7 \\
\hline 5. & $121-130$ & 125.5 & 7 & 7.5 \\
\hline
\end{tabular}

Teacher performance questionnaire data containing 33 closed statement items were obtained from questionnaires that had been distributed to 93 respondents.

Table 7. Description of Teacher Performance (Y)

\begin{tabular}{|l|l|l|}
\hline No & Statistic & Value \\
\hline 1. & Average & 140.00 \\
\hline 2. & Standard Deviation & 19.71 \\
\hline 3. & Median & 142.00 \\
\hline 4. & Mode & 144 \\
\hline 5. & Minimum & 106 \\
\hline 6. & Maximum & 165 \\
\hline
\end{tabular}

Published By: 
The Effect of Participative Leadership of Principal of Private School on Work Motivation of Teacher and their Performance in Tangerang City

Table 8. Frequency distribution of the teacher performance (X2)

\begin{tabular}{|l|l|l|l|l|}
\hline No & Range & Median & Frequency & $\begin{array}{l}\text { Relative } \\
\text { Frequency }\end{array}$ \\
\hline 1. & $101-110$ & 105.5 & 1 & 1.07 \\
\hline 2. & $111-120$ & 115.5 & 8 & 8.61 \\
\hline 3. & $121-130$ & 125.5 & 15 & 16.13 \\
\hline 4. & $131-140$ & 135.5 & 14 & 15.05 \\
\hline 5. & $141-150$ & 145.5 & 38 & 40.86 \\
\hline 6. & $151-160$ & 155.5 & 11 & 11.83 \\
\hline 7. & $161-170$ & 165.5 & 6 & 6.45 \\
\hline
\end{tabular}

Data that had been analyzed by descriptive statistics were then tested in various test before the data was tested for the research hypothesis. The requirements test of this analysis includes normality test, linearity test, and multicollinearity test. The following will explain the results of the requirements test.

Normality test conducted on the participative leadership of principal variable obtained a Kolmogorov-Smirnov $Z$ value of 0.564 with a significance value (p) for participative leadership of principal variable of 0.766 which means that the participative leadership of principal variable was normally distributed. This value was above 0.05 ( $p>0.05$ ). Work motivation of teacher had a Kolmogorov-Smirnov Z value of 0.626 with a significance value (p) for work motivation of teacher was 0.882 , which means the work motivation of teacher variable was normally distributed. Teacher performance had a Kolmogorov-Smirnov $\mathrm{Z}$ value of 0.446 with a significance value (p) for teacher performance variable of 0.618 , which means that the teacher performance variable was normally distributed. The values of participative leadership of principal, teacher motivation and teacher performance were normally distributed because the calculation results of each variable were above 0.05 ( $p$ > $0.05)$.

Linearity test conducted on participative leadership of principal on teacher performance obtained a number of 0.342 $>0.05$. Work motivation on teacher performance obtained a number of $0.486>0.05$. This means that the relationship between the independent variable and the dependent variable was linear.

Multicollinearity test obtained VIF values for each independent variable of 5.216 and 4.122 which was less than 10. This means that there was no multicollinearity between independent variables.

The first hypothesis test was obtained that the coefficient of determination of Adjusted R Square was 0.531, which means the contribution of participative leadership of principal to teacher performance was $53.1 \%$, while the rest was influenced by other factors. With a significance value of regression of 0.015 ( $p<0.05)$, the regression equation was significant. This means that the hypothesis was accepted, which means there was a significant influence indirectly between the principal participatory leadership on teacher performance. The coefficient value for participative leadership of principal was 1.04 , while the constant value was 26.15 so that the double linear regression equation of $\mathrm{Y}=$ $26.15+1.04$ X1.

From the regression equation it can be interpreted that every increase in participative leadership of principal of one point will be followed by an increase in teacher performance by 1.04, while a value of 26.15 means that if there is no participative leadership of principal factor then teacher performance is only 26.15 .

The results of this study indicated participative leadership of principal as one of the important factors in schools, this is in line with the statement that the leadership factor is referred to as a determining factor in the success of the process of autonomy and decentralization of education. On this basis, the school leadership paradigm needs to be directed at the principles of participatory leadership. As expressed by Dimyati (2014, p. 39), participative leadership is a way of leading that allows subordinates to participate in the decision-making process if the process affects the group, or the group (subordinates) are able to play a role in decision making. Yukl (2015, p. 9) stated that leadership is a process of influencing others to understand and agree on what is needed in carrying out a task and how to do that task, as well as a process to facilitate individual and collective efforts to achieve common goals.

The results showed that the indicators of participative leadership of principal were fulfilled. On the consultation dimension, the indicators are 1) Decision making takes into consideration of subordinate's suggestions and input, 2) Communication takes place both vertically and horizontally. In the dimension of joint decision making, the indicators are 1) Decision making regarding policies and activities carried out by the leader together with followers. In the dimension of power distribution, the indicators are 1) Divide the proportion of responsibilities to subordinates, 2) Decision making is fully distributed to all levels of the organization. In the decentralization dimension, the indicators are 1) Submission of functions to subordinates, 2) Responsibility for control is left to the lowest unit. In the empowerment dimension, the indicators are 1) Workers empowerment, 2) Workers are motivated through participation in determining economic rewards, setting goals, improving methods, determining achievement of teacher and employee goals. In the democratic management dimension, the indicators are: 1) The relationship between management and teachers and employees is very close and friendly and mutual trust.

Teacher performance is the result of work achieved by teachers in schools to achieve school goals (Priansa, 2017, p. 136). Performance is an embodiment of ability in the form of real work that is reflected in compliance, commitment, and loyalty in developing students' potential and improving the quality of school.

Leadership has a very important role in improving teacher performance. Principal as a school leader is one of the determining factors that can encourage teachers to be able to realize the vision, mission and the achievement of school goals and objectives through programs that are implemented in a planned and 
gradual manner. Principal as a leader can improve work performance by motivating teachers to further develop their profession so that they will, directly and indirectly, improve teacher performance. To carry out the functions and responsibilities, the principal as a leader uses certain styles to direct the teachers, and school employees to achieve the goals of the school organization namely participatory leadership.

This research gave a meaning that schools need appropriate leadership to improve teacher performance. Based on this, the concept of participative leadership can be considered in improving teacher performance, especially in Korwil I Tangerang Private High School.

The second hypothesis test was obtained that the coefficient of determination of Adjusted R Square was 0.542, which means that the contribution of work motivation to teacher performance was $54.2 \%$, while the rest was influenced by other factors. With a significance value of regression of 0.022 ( $p<0.05$ ), the regression equation was significant. This means that the hypothesis was accepted, which means there was a significant and indirect influence between work motivation on teacher performance. The coefficient value for work motivation was 0.93 , while the constant value was 41.39 so that the double linear regression equation of $\mathrm{Y}=$ $41.39+0.93 \times 2$.

From the regression equation it can be interpreted that each increase in work motivation score of one point will be followed by an increase in teacher performance by 0.93 , while the value of 41.39 means if there is no work motivation factor then teacher performance is only 26.15 .

The results of this study support the theories and opinions that have been put forward in theoretical studies, according to Hanggraeni (2011, p. 31), motivation has a definition as a process that explains the intensity, direction, and perseverance of an individual to achieve the goals. The three main elements of motivation are intensity, direction, and perseverance. Intensity is related to how actively someone tries. Direction is related to link efforts to directions and goals that benefit the organization as well as to consider the quality and intensity of efforts simultaneously. Perseverance is a measure of how long a person can keep the business.

This is reaffirmed by Herzberg, Mausner and Synderman in Wukir (2013, p. 116) which suggested two types of motivation, namely: a) Intrinsic Motivation: factors that come from oneself that influence a person to take certain actions; b) Extrinsic Motivation: factors that come from outside of a person or that other people do to motivate a person.

The results of this study also gave meaning that good work motivation of teacher has been met.

On the intrinsic motivation dimension, these indicators are 1) Responsibility (feel that work is important), 2) Autonomy (freedom of action), 3) Opportunity to progress, 4) Develop skills, 5) Do interesting and challenging work.

On the dimensions of extrinsic motivation, these indicators are 1) Giving awards, 2) Giving salary increases or promotions, 3) Discipline actions, 4) Sanction or criticism. Extrinsic motivation has a fast and strong effect but usually doesn't last long. Intrinsic motivation usually lasts a long time because it is inherent in the individual.

Hoy and Miskel's opinion as quoted by Husien (2017, p. 135) stated that teacher performance is an ability to carry out tasks or jobs in accordance with the attitudes, knowledge and skills and motivation of employees.

Work motivation is a strong desire in someone or something that causes the teacher to work to complete the assignments. Work motivation must always be maintained so that a teacher is always enthusiastic and passionate in carrying out daily tasks. Teachers who are highly motivated will certainly develop their abilities because of the drive to excel, to encourage and develop their abilities and energy to achieve maximum performance.

Work motivation related to teacher performance is due to the encouragement or motivation of someone who arises either from oneself or the influence of the work environment that can cause someone to move to do something, so that the duties and responsibilities of teachers can be carried out optimally, the results of their work can be seen real.

In general, high performance is associated with high motivation. Under any circumstances, however, if there is encouragement or motivation, a teacher will carry out the tasks that are tailored to the priorities of the work, not according to what is easy or desirable. Conversely, low motivation is associated with low performance.

The results of this study indicated that work motivation is a process of potential strength that exists within a person as well as outside oneself that explains the direction, intensity and perseverance carried out to improve teacher performance, especially in Korwil I Tangerang Private High School.

The third hypothesis test was obtained that the coefficient of determination of Adjusted R Square was 0.643, which means the contribution of participative leadership of principal and work motivation of teacher on teacher performance was $64.3 \%$, while the rest was influenced by other factors. With a significance value of regression of 0.027 ( $p<0.05$ ), the regression equation is significant. This means that the hypothesis is accepted, which means there is a significant influence indirectly between the participative leadership of principal and work motivation on teacher performance. The double linear regression equation is $\mathrm{Y}=21.15+0.73 \mathrm{X} 1$ $+0.65 \mathrm{X} 2$.

The results of this study supported the theories and opinions that have been put forward in theoretical studies, according to Yukl (2015, p. 9) that leadership is the process of influencing others to understand and agree on what is needed in carrying out a task and how to do that task, as well as a process to facilitate individual and collective efforts to achieve shared goals. Dimyati (2014, p. 39) stated that participative leadership of principal is a way of leading that allows subordinates to participate in the decision-making process if the process affects the group, or the group (subordinates) are able to play a role in decision making.

Performance is an embodiment of ability in the form of real work that is reflected in compliance, commitment, and loyalty in developing students' potential and improving the quality of school.

Leadership in the school environment involves principal efforts to influence the attitudes and behavior of teachers in carrying out daily tasks. Principal as a leader must be able to understand, choose, and formulate educational goals that will be achieved in the success of 
educational programs that become the vision and mission of the school and create schools as a harmonious, healthy, dynamic and comfortable work environment. This will cause and strengthen teachers to be more motivated and have high work motivation, so they have a strong desire that causes teachers to work to complete their assignments properly. Work motivation must always be maintained so that a teacher is always enthusiastic and passionate in carrying out daily tasks. Teachers who are highly motivated will certainly develop their abilities because of the drive to excel, to encourage and develop their abilities and energy to achieve maximum performance. The proper implementation of participative leadership of principal will increase teacher work motivation so that teacher performance can be realized optimally.

Thus the good quality of participative leadership of principal and high work motivation will improve the quality of teacher performance, and vice versa.

\section{CONCLUSION AND SUGGESTION}

\section{Conclusion}

This study obtained information that the contribution of participative leadership of principal to teacher performance was $53.1 \%$. The contribution of work motivation of teacher to teacher performance was $54.2 \%$. The contribution of participative leadership of principal and work motivation of teacher to teacher performance amounted was $64.3 \%$, while the rest was influenced by other factors.

Besides that, it can also be concluded that there was a partial positive relationship, both on the participative leadership of principal (X1) and work motivation of teacher (X2). The participative leadership of principal variable produced an appropriate regression equation, $\mathrm{Y}=26.15+$ $1.04 \mathrm{X} 1$. The work motivation of teacher can be seen in regression equation $\mathrm{Y}=41.39+0.93 \mathrm{X} 2$. While simultaneously, a significant regression equation $\mathrm{Y}=21.15$ $+0.73 \mathrm{X} 1+0.65 \mathrm{X} 2$ was obtained.

\section{Suggestion}

Based on the findings of this study, principals in particular in the city of Tangerang are expected to be able to develop their leadership by being expected to try and be able to in a participatory form and be able to implement participative leadership to motivate teacher.

\section{REFERENCES}

1. Adi, B. W. (2013). Analisis Pengaruh Budaya Organisasi, Kepemimpinan dan Motivasi Kerja terhadap Komitmen Organisasi dan Implikasinya pada Kinerja Principal. Jurnal Pendidikan Dan Kebudayaan, 19(2), 206-221.

2. Baharun, H. (2017). Peningkatan Kompetensi Guru Melalui Sistem Kepemimpinan Kepala Madrasah. At-Tajdid: Jurnal Ilmu Tarbiyah, 6(1), 1-26.

3. Basri, H. (2014). Kepemimpinan Principal. Bandung: Pustaka Setia.

4. Bush, T. (2007). Educational leadership and management: Theory, policy and practice. South African Journal of Education, 27(3), 391-406.

5. Dimyati, H. (2014). Model Kepemimpinan dan Sistem Pengambilan Keputusan. Bandung: Pustaka Setia.

6. Fatchurrochman, R. (2011). Pengaruh motivasi berprestasi terhadap kesiapan belajar, pelaksanaan prakerin dan pencapaian kompetensi mata pelajaran produktif. Invotech, $\operatorname{VII}(2), 164-174$.
7. Hanggraeni, D. (2011). Perilaku Organisasi: Teori, Kasus, dan Analisis. Jakarta: Lembaga Penerbit Fakultas Ekonomi Universitas Indonesia.

8. Husien, L. (2017). Profesi Keguruan: Menjadi Guru Profesional. Yogyakarta: Pustaka Baru Press.

9. Manik, E., \& Bustomi, K. (2011). Pengaruh Kepemimpinan Principal, Budaya Organisasi dan Motivasi Kerja Terhadap Kinerja guru pada SMP Negeri 3 Rancaekek. Jurnal Ekonomi, Bisnis \& Entrepreneurship, 5(2), 97-107.

10. Mbeu, L. O. M., \& Anwar. (2011). Pengembangan Model Kepemimpinan Principal yang Efektif. Jurnal Pendidikan Dan Kebudayaan, 17(2), 215-224.

11. Northouse, P. G. (2017). Leadership : Theory and Practice (7th editio). Western Michigan University USA: SAGE Publications.

12. Priansa, D. J. (2017). Menjadi Principal dan Guru Profesional. Konsep, Peran Strategis, dan Pengembangannya. Bandung: Pustaka Setia.

13. Siregar, S. (2015). Statistik Parametrik Untuk Penelitian Kuantitatif: Dilengkapi dengan Perhitungan Manual dan Aplikasi SPSS Versi 17. Jakarta: Bumi Aksara.

14. Somech, A. (2005). Directive versus participative leadership: Two complementary approaches to managing school effectiveness. Educational Administration Quarterly, 41(5), 777-800.

15. Sugiyono. (2014). Metode Penelitian Kuantitatif, Kualitatif, dan Kombinasi (Mixed Methods). Bandung: Alfabeta.

16. Susanto, A. (2016). Manajemen Peningkatan Kinerja Guru : Konsep, Strategi, dan Implementasinya. Jakarta: Prenadamedia Group.

17. Werang, B. R. (2014). Pengaruh Kepemimpinan Transformasional Principal, Moral Kerja

18. Guru, dan Kepuasan kerja terhadap Kinerja Guru. Cakrawala Pendidikan, XXXIII(1), 128-

19. 137

20. Wirawan. (2014). Kepemimpinan: Teori, Psikologi, Perilaku Organisasi, Aplikasi, dan Penelitian. Jakarta: Rajawali Press.

21. Wukir. (2013). Manajemen Sumber Daya Manusia Dalam Organisasi Sekolah. Yogyakarta: Multi Presindo.

22. Yukl, G. (2015). Kepemimpinan dalam Organisasi (7th editio). Jakarta Indeks.

23. Yusuf, M. (2010). Studi Efektivitas Program Akselerasi di SMU Surakarta. Jurnal Pendidikan Dan Kebudayaan, 16(I), 1-12. 